\title{
Mensaje festivo y estética desgarrada: la dura pedagogía de la celebración barroca
}

\author{
León Carlos Álvarez Santaló*
}

\begin{abstract}
RESUMEN
La fiesta religiosa barroca, junto a demostraciones de mayor cuantía y amplio contenido simbólico, incluyó otros aspectos de mayor carga combativa e ideología militante. Su expresión más frecuente fueron los emblemas (pintura rnás epigrama) con envoltura de poesía popular e incluso, en imitación del teatro, villancicos cantados en las solemnidades litúrgicas con estética villana y mensajes elementales de violencia antisemita 0 antimorisca. Un ejemplo jugoso de tales propuestas puede encontrarse en esta fiesta de 1664, de organización y diseño inquisitorial, de

ABSTRACT

The religious festivals, all together with demonstrations of higher importance and simbolic contents, included other aspects provided with a fighting intention and militant ideology. Its most frequent expression was the emblem (painting plus epigram), wrapped with popular poetry and even, imitating drama, with rustic carols sung in liturgical solemnities and containing plain messages of antisemite or antimoorish violence. A substantial example can be found in this article, wich deals with a festival organizd by the Inquisition in 1664 and its flagrant pedagogy for common people.
\end{abstract} la que se analiza la pedagogía populista más flagrante.

* Departamento de Historia Moderna. Universidad de Sevilla. 
«Por otra parte para el elogio y la censura son pertinentes, también, lugares comunes... presentando, por ejemplo, al precavido como frío y calculador, al simple como honesto o al insensible como pacífico... así, hay que presentar al que es iracundo y furioso como franco, al arrogante como magnificente y digno... al osado como valeroso, al manirroto como liberal, pues esto es, en definitiva, lo que le parecerá a la mayoría de la gente».

Aristóteles, Retórica

Ninguna sorpresa se esconde en considerar la fiesta barroca como una gran pedagogía semijeroglífica y semievidente. No sólo eso, desde luego, pero suficientemente eso como para que tal calificación haya podido primar sobre otros parámetros de la fiesta igualmente sugestivos. Pedagogía por barroca y pedagogía por fiesta. Refiriéndose a la plástica general del arte barroco, Emilio Orozco se refiere a esta pedagogía, en los siguientes términos: "Y hay otro aspecto de esta exaltación naturalista de nuestra pintura (barroca) que nos descubre, igualmente, una visión trascendente de lo real... nos referimos al destacar con la técnica el cómo son y el cómo están hechas las cosas... la realidad, en sus más varias calidades, se destaca con la factura... como si se persiguiera más que imitar la naturaleza imitar el crear de la naturaleza" '.

Un paso más adelante y más crudo en la pedagogía, lo proponían los padres de Trento en la sesión vigésimoquinta: "Enseñen diligentemente los obispos que por medio de las historias de los misterios de nuestra redención, expresadas en pinturas y en otras imágenes, se instruye y confirma al pueblo en los artículos de la fé... que de todas las imágenes sagradas se saca gran fruto... porque se ponen a la vista del pueblo los milagros que Dios ha obrado por medio de los santos y los ejemplos saludables de sus vidas, a fin de que... se muevan a amar a Dios por ellos y conforme su vida y costumbres a imitación de las de los santos" 2 . Francisco de Borja, en absoluta sintonía con el hallazgo ignaciano de la contemplación imaginativa, advierte: «...el oficio que hace la imagen es como dar guisado el manjar que se ha de comer de manera que no queda sino comerlo" ${ }^{3}$. Todo ello desemboca, de modo natural, en incorporar a tal pedagogía la técnica de las técnicas al respecto, es decir, la Retórica de Aristóteles, cuna y molde de todas las estudiadas y compuestas en el

Orozco Diaz, E., Temas del Barroco de poesía y pintura. Granada, 1989, pág. XLIV.

El texto ha sido citado con profusión; vid. p.e. Santiago SeBAstián, Contrarreforma y Barroco. Madrid, 1981, pág. 62.

3 Ibidem, pág. 63. 
barroco. Santiago Sebastián nos recuerda, en efecto: "por otra parte, la retórica será una idea aristotélica fundamental, en el sentido de arte de persuadir por medio del discurso político, pero desde el siglo XVI, tal procedimiento será también aplicado a las artes y aparecerá perfectamente adaptado al arte barroco del siglo xvili... No ésta sólo relacionada (la retórica) con los textos literarios, de modo que podemos hablar de una retórica de la arquitectura (abrumadora en la efímera festiva, justamente, añado yo) y de las otras artes plásticas, aunque, en general, obra en todas conjuntamente ${ }^{4}$. Referiéndome precisamente a tales enredos seductorescoactivos, propuse, en otro trabajo, que estamos obligados a considerar la fiesta religiosa barroca, convocatoria urbana para la exaltación y el aprendizaje del modelo ideológico, como «...probablemente el conjunto estructurado más eficaz que se haya puesto en práctica para conseguir la transferencia de modelos del mundo, desde sus detentadores dirigentes hacia la clientela masiva» ${ }^{5}$. Pues bien, para conseguirlo, resulta indispensable la tecné retórica. Entre otras cosas, porque ella era el modelo de trabajo persuasivo de mayor y más largo prestigio para esa época y con el que estaban familiarizados, a fondo, los más frecuentes responsables del diseño festivo, clérigos o humanistas (tardíos pero no menos eruditos que los tempranos). J.A. Maravall ha insistido hasta la abrumación en esta pedagogía como arma de combate. Aludiendo al efectismo tremendista comenta: "desde luego, magnificencia-desmesura-terribilidad-extremosidad van eslabonadas, en fuerte conexión; aunque no haya que ver en ello una consecuencia, pura y simple, de un juego retórico sino que este se produce con sus posibilidades de acción sobre el animo del destinatario...». Aquí, la palabra clave es «juego» pues difícilmente la retórica como técnica de persuasión podría considerarse tal. Maravall insiste en la pedagogía del espanto y de la sorpresa (cuyo arco sensorial, por cierto, es lo suficientemente amplio para que quepan en él desde artefactos simplemente ingeniosos hasta composiciones poéticas o maniquíes simbólicos) recordándonos: «si la teoría aristotélica del asombro se ha leído en el

\footnotetext{
4 Ibidem, pág. 14. En el prólogo de ese libro, Rodriguez G. DE Ceballos comenta: «Posiblemente es este prurito retórico (ut rethorica pictura) el denominador común que amalgama manifestaciones divergentes y aún contradictorias del barroco europeo, tanto en los paises católicos como protestantes, lo mismo en el ámbito de la Iglesia que en el del Estado" (pág. 10).

5 Álvarez Santaló, L.C., “El espectáculo religioso barroco», Manuscrits, n. ${ }^{\circ} 13,1995$, pág. 158. Lo de la clientela masiva es, para empezar, un principio de exigencia retórica bien asentado por Aristóteles en el libro I de su Retórica: "Asimismo, lo que todos eligen es mayor que lo que no es elegido por todos. Igual que lo que elige la mayoría frente a lo que elige la minoría pues (ya dijimos que) lo bueno era aquello a lo que aspiran todos, de suerte que será mayor lo que desean los más... algunas veces, es mayor aquello en lo que todos participan ya que constituiria una deshonra no participar en ello". ARIstótelES, Retórica. Madrid, 1990, pág. 232.
} 
Renacimiento y se seguirá leyendo y recordando en el Barroco, en este segundo período se busca en el asombro... la idea de algo diferente a una introducción o acceso al saber; más bien la de un efecto psicológico que provoca una retención de las fuerzas de la contemplación o la admiración durante unos instantes, para dejarlas actuar con más vigor al desatarlas después"; y también: "si la pedagogía y todas las artes de conducir el comportamiento humano en el Barroco procuran llegar a niveles extrarracionales del individuo y desde allí moverle e integrarle en los grupos mantenedores del sistema social vigente, un gran recurso es el de llamar la atención con el suspense de la novedad siempre que no entrañe riesgo" 6 . El maestro Orozco le dedicó al asunto algunas páginas, no hace tantos años. Se refería a estas fiestas de la pedagogía barroca como «la reunión de todas las artes, incluida la poesía que actuaba, asi, visualmente». Como éste trabajo trata, sustancialmente, de un fragmento de esta poesía festiva (en este caso brutalmente populista), tal vez merezca la pena ampliar la cita: «pero, además, hay que unir a esa teatralización de lo poético, las formas síntesis de todas las artes visuales, incluida la poesía, constituidas por las ya citadas grandes y decorativas arquitecturas de arcos de triunfo, catafalcos, empalizadas y altares de fiestas religiosas y civiles, donde la poesía se visualizaba teatralmente, con pleno valor plástico, enmarcada en cartelas o tarjones, lápidas o inscripciones colocadas en basamentos y frisos... a veces unidas a imágenes principalmente pintadas, con figuras y escenas especialmente alegóricas, sobre todo de tipo emblemático, enigmas o jeroglíficos" ${ }^{7}$. Cuando hablamos de la retórica aristotélica, desafortunadamente, una cierta imagen de estilismo farragoso se apropia del término, en un desliz semántico que habría dejado perplejo e indignado al mismo Aristóteles. Muy por el contrario, él había construido ( $y$ en ese sentido la utilizo aquí) una afilada maquinaria para la deliberación, la convicción y el panegírico (u ocasionalmente el dicterio) cuya espina dorsal era el conocimiento de la organización del lenguaje y el de las pasiones humanas que habian de recibirlo y reaccionar según su capacidad de impacto o seducción. En otro lugar, intente demostrar que todo el diseño de la fiesta barroca (y la religiosa con especial cuidado) era una gigantesca maquinaria retórica perfectamente engrasada y afinada: «toda ella (la retórica) se concibe, en efecto, y expresamente, desde Aristóteles, como una construcción sabia de iazadas y relaciones eficaces entre la taxis y la lexis, es decir, entre el orden interior y el expresivo; entre la in-

6 Maravall, J.A., La cultura del Barroco. Madrid, 1975, págs. 427, 433 y 453.

Orozco Díaz, E., Introducción al barroco. Granada, 1988, vol. I, pág. 297. 
trincada geometría de la disposición de un fondo argumental y la eficiente exhibición de tal fondo a través de una forma, no sólo (aunque en primer lugar) adecuada sino convincente" ${ }^{8}$. Citaba entonces y cito ahora a Aristóteles mismo a comienzos del libro III de su Retórica: «nos queda ahora por hablar acerca de la expresión, dado que no basta con saber lo que hay que decir sino que también es necesario decirlo como se debe y esto contribuye mucho a que se manifieste de qué clase es el discurso. Así pues, de acuerdo con la naturaleza (del asunto) primero investigamos lo que es naturalmente primero, a saber, las materias mismas a partir de las cuales se obtiene la convicción; pero en segundo lugar (investigamos) el modo cómo estas materias predisponen los ánimos mediante la expresión; y en tercer lugar, cosa que es potencialmente importantísima,... aquello que concierne a la representación» ".

Partiendo pues de esta base, digamos, contrastada, vamos a comprobar una parte de esta pedagogía, una pequeña, en apariencia pero eficaz. Pequeña si la comparamos con otras estilísticas festivas de gran aparato (arquitecturas efímeras, carrozas, batallas fingidas, representaciones simbólicas o fuegos de artificio acumulados hasta el peligro de incendios reales) pero sumamente eficaz para fijar mensajes "de batalla» (de la ideológica, esperadamente, pero no sólo ni únicamente de ella) con cierta violencia y muy poca cobertura simbólica. La cobertura simbólica, en la fiesta, tiene todo que ver con la imprescindible y prevista transformación de la realidad en mirabilia, pero también ofrece la dificultad de oscurecer los mensajes según qué públicos y qué entendederas. Como de pedagogía sensorial hablamos, vamos a examinar alguna de las más pedestres, preparadas para cubrir, con toda claridad y descarnadura, los flancos comprensivos que los simbolismos más eruditos o jeroglíficos hubiesen podido dejar indemnes, en el ataque ideológico.

\footnotetext{
8 Álvarez SANTALó, L.C., "La fiesta religiosa barroca y la ciudad mental», en VV.AA., La religiosidad popular andaluza, Instituto de Estudics Almerienses. Almería, 1998 (en prensa, de inmediata publicación).

9 ARISTÓTELES, Retórica, op. cit., págs. 479-480. Las citas podrían multiplicarse hasta el infinito; tomemos, por ejemplo, esta otra en que se enfrenta con la moralidad del uso de trucos expresivos: «... como todas las materias que se refieren a la retórica se relacionan con la opinión (del público) se ha de poner también cuidado en este punto, no por su rectitud sino por su necesidad. Porque lo justo y nada más que ello es lo que hay que buscar en el discurso, antes que no disgustar o el regocijar al auditorio... de suerte que todo lo que queda de la demostración es superfluo. Con todo, al mismo tiempo es potencialmente importante (la técnica expresiva), como ya hemos dicho, a causa de los vicios del auditorio. Y por lo tanto, lo que concierne a la expresión es también... necesario en toda enseñanza... que todo es cosa de la fantasia y dirigida al oyente" (ibidem, págs. 482 y 483). Ni que decir tiene que los diseñadores de las fiestas barrocas tenían muy en cuenta estos «vicios» de los espectadores-auditorio y, no digamos, esta apelación a la fantasía como técnica conocida de la recepción pedagógica.
} 
Comenzaremos por recordar, aunque debería ser innecesario, que las descripciones de fiestas constituyen un texto, escrito, donde la fiesta se ha construido de nuevo y con exquisito cuidado retórico, en función de la percepción del autor y de sus intenciones. Estas últimas, naturalmente, de acuerdo con las reglas retóricas, no serán, con toda probabilidad, las que tal autor incluya en la introducción de su escrito, o no lo serán de modo exclusivo y aún ni principal. Como la fiesta "verdadera» de la calle ya era un discurso, retórico, lo que llega hasta nosotros es el discurso del discurso 0 , lo que resulta aún más sugestivo, un discurso segundo que va a sustituir, ya para siempre, al discurso primero que estuvo alguna vez en la plaza y la calle.

Es, por tanto, una re-construcción de la fiesta que puede y debe alzarse con una identidad, en cierto sentido, nueva y diferente y con una intencionalidad descarnada ya de los ropajes simbólicos de la fiesta-real. Pero sucede que, a partir de la descripción, será ésta, la escrita, y no aquella, la que anduvo la calle, la única fiesta real. Incluso un lector que estuviera presente en la de la calle, adecuará su «memoria» a lo que tiene en presencia, en el texto; la adecuará, sobre todo y evidentemente, porque hallará en el texto todo lo que no vio o no entendió y lo que vio y creyó entender se le despliega ahora con otros detalles y otras explicaciones. No son, pues, estos textos-descripción solo un festín para la memoria evocadora sino, sobre todo, una sustitución eficaz de lo real, y única realidad festiva que quedará fraguada para los lectores ${ }^{10}$. Esta característica re-

10 Vid. Rey Castelao, Ofelia, «Historia e imaginación: La fiesta ficticia», en El Rostro $y$ el Discurso de la fiesta, Manuel Núñez Rodríguez (ed.). Santiago de Compostela, 1994, págs. 185196. Refiriéndose al texto descriptivo de unas fiestas concretas afirma: «...diversos relatos en los que se ofrecen al lector una amplia gama de recursos y referencias con los que reconstruir, mentalmente, una visión grandiosa de una fiesta que, en realidad, resultaba indiferente, a efectos del objetivo que se perseguía, que se celebrase o no, o que, de celebrarse, respondiese al relato, porque lo que se pretendia era captar al lector — de cuya imaginación y sensibilidad la reconstrucción ideal a partir de una descripción muy prolija- y suministrar argumentos emotivos a quienes la transmitian verbalmente, esto es, predicadores que encontraban en esas descripciones una batería de recursos de efecto previsible" (págs. 186-187). No puedo estar de acuerdo, totalmente, con la afirmación de que era indiferente que la fiesta se haya celebrado o no; la percección de que se está ante una realidad, resulta imprescindible para el proceso de transmutación hacia las mirabilia. El resto de sus apreciaciones, por el contrario, es absolutamente compartible. Vid. también GARCía BERNAL, J., «Vínculo social y vínculo espiritual: La fiesta pública en la España moderna", en Fêtes et Divertissements Ibericas, n. ${ }^{\circ} 8$, París, 1997, págs. 15-40, especialmente el último epígrafe ( «los libros de la fiesta...»). Dice allí, por ejemplo, que la fiesta debe consíderarse como «... una fórmula que permitía proyectar los nuevos elementos conformadores de la personalidad (individualismo, autocontrol, estatus, riqueza) en un ámbito de resonancia social, donde fueran identificados, justipreciados $y$, entonces también, sujetos de negociación y competencia. Esta fórmula cultural fue la gran ceremonia urbana que encontramos en pinturas, grabados $y$, sobretodo, en los cientos de relaciones de fiestas que se escribieron con el propósito de 
sulta de la mayor importancia respecto de uno de los componentes sustanciales de la fiesta: la poesía implicada en las pinturas, las músicas y las arquitecturas. Tanto la erudita (de la que no voy a ocuparme) como la voluntariamente diseñada como popular, en la fiesta real, han pasado relativamente desapercibidas, con la mayor probabilidad, porque en el festín visual (sobre todo visual, no lo olvidemos) que toda fiesta representa, las cartelas con versos son, comparativamente, desdibujadas u opacas a las retinas desaforadas; e incluso si fueron advertidas, con atención, han sido ya olvidadas. El texto, entonces, las recoge con amorosa y muy intencionada morosidad y detalle y las mantiene no ya como parte de la organizada belleza efímera que fueron sino como recordatorio marmóreo y permanente que ahora son; garantiza su uso y su memorización-aprendizaje (si tal fuera el caso y la voluntad del lector) multiplicando, sin esfuerzo, la frecuencia y la intensidad de su efecto.

El ejemplo a utilizar aquí, en orden a la necesaria brevedad, será la descripción de la fiesta que el tribunal de la Inquisición de Granada organizó, en 1664, para celebrar la beatificación «del glorioso y Invicto Mártir Pedro de Arbues, canónigo de la Santa Iglesia Metropolitana de Zaragoza, primer Inquisidor del Reyno de Aragón". La escribió el Maestro Agustín Martínez de Bustos, Beneficiado más antiguo de Ntra. Señora de las Angustias y Comisario del Santo Oficio, y se publicó en Granada en la Imprenta Real de Baltasar de Bolívar, en la calle Abenamar, ese mismo año de $1664^{11}$.

El autor comienza, dedicando su descripción al Tribunal del Santo Oficio de la Inquisición y, cumpliendo con la norma retórica, justificando el motivo y presentándose con la debida modestia: «ofrezco a V.S. esta Descripción, hija de mi fervoroso afecto, a que me dió motivo la devoción que le he cobrado a nuestro Esclarecido Mártir. Confieso tendrá en sí algunos hierros que por la brevedad del tiempo no los ha podido morder la lima; más servirán de materia a la piedad de V.S. a quien suplico me perdone el aver querido reducir las dilatadas Grandezas y Pompas de la Fiesta a una breve suma. Guarde Dios a V.S. para defensa de nuestra Santa Fe. Su menor capellán...». De entrada, según esto, quedan claros

\footnotetext{
inmortalizarlas... auténticos memoriales socioinstitucionales del prestigio" (pág. 39). Vid. también, del mismo autor, «Lo serio y lo burlesco: la máscara Barroca como forma de pedagogía popular», en Demófilo, n. ${ }^{\circ}$ 18, Sevilla, 1996, págs. 31-48.

11 No dispongo del original sino de fotocopia de catorce hojas (veintiocho páginas) que no sé si corresponden a un tomo encuadernado. Al ser un texto tan breve no parece funcional remitir, en las abundantes y continuas citas que recojo, a notas con el número de la página correspondiente que harían farragosa la lectura seguida.
} 
algunos puntos retóricos: primero, que, aparentemente, el texto no está previsto para un público general sino como un «informe», neutral, para que el mismo Tribunal organizador guarde memoria detallada de su propia y, naturalmente, meritoria celebración (pero, entonces, ¿por qué imprimirla?); segundo, que el "verdadero» motivo de escribir no es otro que el «fervoroso afecto» y la «devoción» y, que, por ende, no le ha movido ningún otro interés, ni siquiera el legítimo de extender esta devoción a un futuro público-lector; tercero, que el autor, "naturalmente", no ha sido capaz de igualar con su texto la magnificencia de la obra del Santo Tribunal y que deben excusarse las imperfecciones. Todo en la más ortodoxa línea retórica de un exordio breve que predisponga a la benevolencia, pero en modo alguno realista.

Pasaremos por alto las descripciones de los distintos preparativos, circunstancias y propósitos, en los que va glorificándose al Tribunal poniendo de manifiesto, no sólo la absoluta sincronía con las otras instituciones del poder urbano (Cabildo municipal, Cabildo eclesiástico y Prelado, aunque no a la Audiencia) sino la reverencia y devoción que todas ellas mostraban al Tribunal. Ninguna frase caería en saco roto para un lector incluso descuidado. Así, el Cabildo eclesiástico, cuyos agravios con la inquisición (protocolarios o de mayor cuantía) eran notorios y habian provocado escándalos de cierta entidad en Granada, como en otras ciudades, acogía la invitación a colaborar en la fiesta con absoluta y entusiasta dedicación («en cuyos piadosos coraçones halló la nueva el devido, afectuoso y devoto acogimiento que se esperava, ofreciendo con liberal grandeza quanto valiessen en orden a servir al Santo Tribunal...»); por lo que al Cabildo civil se refiere la cosa parecía aún más estrecha pues varios de sus caballeros Veinticuatros eran, al mismo tiempo, familiares del Santo Oficio y así «Don Christoval de Castillejo, Familiar del Santo Oficio y Veintiquatro más antiguo desta Ciudad y Decano del dicho Cabildo y su Procurador de Cortes que ha sido, en nombre del, respondió que hazían la estimación devida de que el Tribunal del Santo Oficio le huviese dado noticia de tan alegre nueva para mostrar la grande voluntad y deseo que tenía de servir al Santo Oficio". El asunto de las "servidumbres", devociones y gratitudes al Tribunal se extiende por un par de páginas de modo que no quepa duda alguna, a cualquier lector de buena voluntad (y no demasiado bien informado de los chismes de las querellas institucionales), que la verdadera cúpula del poder granadino, de facto, era el Santo Tribunal. Pero, como dije, pasaremos por alto el detalle y pormenor de tan bien trabada pedagogía "general», para concentrarnos en otros elementos más directos.

A estas alturas, cualquier conocedor de la retórica clásica se estará preguntando a qué clase de discursos corresponden los textos festivos. En 
efecto, como es bien sabido, Aristóteles estimaba que el discurso retórico se divide en tres géneros, el deliberativo, el judicial y el epidíctico, que corresponden a las tres clases de público posibles (el de la discusión política, el del pleito jurídico y el del homenaje panegírico); el primero toma como su objeto el consejo y la disuasión, el segundo, la acusación y la defensa, el tercero, el elogio y la censura ${ }^{12}$.

En mi opinión la descripción festiva se mantiene a caballo entre el primero y el tercero, aunque es evidente que la mayor parte de su contenido es un panegírico palmario. Al respecto, Aristóteles suponía que la deliberación se ejerce siempre sobre el futuro (qué ha de hacerse), los juicios sobre el pasado (qué sucedió) y los panegíricos o censuras sobre el presente (quién o qué merecen ahora el elogio o el desprecio); en esta perspectiva parece que, siendo la fiesta un pasado, su descripción no podría encajar en el panegírico (epidíctico). De hecho no es así pues, como ya advertí antes, estas descripciones, so pretexto de la memoria, han sido construidas como una realidad presente y para que actúen sobre el lector como una fiesta presente, que es la única real mientras se está leyendo y cada vez que se lea. En cualquier caso, aún concediendo que la descripción es pasado, no hay dificultad en integrarla en el género epidíctico puesto que Aristóteles ya advierte: «...y para el discurso epidíctico el tiempo principal es el presente puesto que todos alaban y censuran conforme a lo que es pertinente aunque muchas veces puede actualizarse lo pasado por medio de la memoria y lo futuro usando de conjeturas» ${ }^{13}$.

Partiendo, pues, del supuesto de que la descripción festiva es sustancialmente un Panegírico, se comprenden mejor los contenidos y el artificio retórico de su organización y presentación. En el caso que nos ocupa, el conjunto es un monumento panegírico al Tribunal del Santo Oficio; los subpanegíricos que contiene (de personas, instituciones, público devoto o el santo mismo celebrado) sólo son arbotantes retóricos de aquella gran bóveda; incluso el elogio de la $\mathrm{Fe}$ o de la Iglesia, están enredados tan estrechamente con el del Tribunal que es éste el protagonista indiscutido, que jamás abandona el proscenio escénico ni los ojos y las entendederas del lector. Contando la portada y la dedicatoria, en las cinco primeras páginas del texto, el lector se ha encontrado veintisiete veces los términos Tribunal del Santo Oficio, Inquisidor, Tribunal de la Santa Inquisición, Santo Tribunal o Santo Oficio de la Inquisición; no puede caber duda alguna de quien es el protagonista del panegírico, in-

\footnotetext{
ARIstóteles, Retórica, op. cit, lib. l, págs. 193 y ss.

Ibidem, pág. 195.
} 
cluso antes de entrar en descripción alguna, ya que en esas páginas sólo se habla de preparativos.

Pasando ahora al nudo de la cuestión nos concentraremos en uno de los espacios festivos descritos, para encontrar allí los mensajes más directos y populistas. Se trata del compás del convento de Santa Cruz la Real que había sido el elegido para la celebración: "continuose el adorno del compás que es muy grande y para que tuviese igual cuadratura se hizo una empalizada la qual se colgó de terciopelos y damascos... y se repartieron por todo el circuito del compás algunos Geroglíficos o pensamientos tocantes a la Vida. Excelencias y Martirio de nuestro Santo; los lienzos fueron pintados al olio, capaces, y la pintura de toda perfección y en los mismos lienzos, fingida, una guarnición de la mesma pintura con aguallones y molduras de oro...». No parece sino que Emilio Orozco hubiese tenido delante el texto cuando escribía sobre la poesía de las empalizadas, en la cita que utilicé páginas atrás. Porque, en efecto, en esta empalizada de terciopelos y damascos se alinearon los jeroglíficos (en realidad emblemas) con sus «explicaciones» en verso ${ }^{14}$. Reproduciré algunas de aquellas tercetas, absolutamente populares y ripiosas, pero cuyo sentido no podía quedar oscuro si no fuese a verdaderos adoquines; todo el compás, pues, quedó convertido en un gigantesco cartelón de ciego, al que sólo faltó que algún clérigo inquisitorial, puntero en mano, lo fuese señalando; en su ausencia, el cronista asume este papel, describiéndolos uno por uno; «jeroglíficos» y versos como los siguientes:

«Pintose un Pelícano, en cuyo pecho, de plumas blancas y negras, se entretexía una Cruz como las que usan los Ministros del Santo Oficio. De los brazos y pies de la Cruz salían unos caños de sangre que yvan a dar a unos pequeños hijuelos que alimentaba con su propia sangre. La (inscripción) latina: Sic hic quos diligo. Y la castellana: Aquella sangre de Pedro / que a la Iglesia ilustra tanto / sustenta este Oficio Santo».

Como se advierte, el comentario latino, para paladares más cultos, no tiene nada que ver con los versos castellanos para el consumo de cual-

\footnotetext{
14 Refiriéndose a esta poesía «visual», de mejor o peor factura literaria, Orozco señala: «el refuerzo de lo visual y su material existencia de objeto a leer y contemplar -y todo ello dentro de un conjunto de por si significativo- le hacia cobrar al poema su completa eficacia sobre el lector, precisamente porque visualizado en dicha forma, cobraba su pleno sentido funcional estéticomoral» (Introd... op. cit., pág. 298). Y más adelarite amplía: “..la lectura de los poemas en su sitio, enlazados con imágenes, jeroglíficos y alegorías... habian de producir un efecto complejo, teatral, cual si nos hablase todo ello directamente. Los versos eran, en cierto modo, como el texto dramático en el teatro, en el sentido de que, igual que en la comunicación teatral, escuchamos las palabras al mismo tiempo que, visualmente, nos están impresionando todos los elementos escenográficos" (ibidem, pág. 308).
} 
quier curioso (devoto o accidental); estos últimos, por el contrario, están obligados a dar cuenta cabal de la pintura simbólica del emblema ${ }^{15}$. A retener, igualmente, que dicha pintura (el pelícano sagrado-redentor), con un simbolismo trillado y sencillo, ha sufrido las transformaciones necesarias (y evidentes) para incorporarse al panegírico inquisitorial; en efecto, el pelícano se utilizaba tópicamente como símbolo eucarístico 0 , como mucho, símbolo de la Madre-Iglesia, mientras que aquí se le hace simbolizar al inquisidor mártir (para eso está la cruz inquisitorial que luce en su pecho) lo que no deja de ser una devota osadía y un tour de force propagandístico a cara descubierta. Se advertirá, también, la distancia estético-emotiva entre la inscripción latina, contenida, elegante, sugerente apenas respecto a la imagen, «Así para aquellos a los que amo», y la «brutalidad» visceral de la terceta en la que los inquisidores se alimentan, físicamente, de la sangre de su protomártir. La inscripción latina confirma, además, el deslizamiento al que antes me refería, pues esa frase sólo puede ser atribuida a Cristo (al igual que el pelícano) mientras la terceta cambia de protagonista, de manera casi impropia, pero en absoluto inocente (un miembro del clero, culto, no podía ignorar el extremoso giro de proponer a un beato como un alter cristus). En cualquier caso, el desgarro naturalista de los mensajes barrocos ha sido considerado, prácticamente sin fisuras, como uno de los parámetros decisivos de su estética. En los mejores casos (Emilio Orozco) vinculándolo a la peculiar intensidad de una religiosidad de la culpa «no centrada en lo bello, ni en lo sereno y equilibrado sino en lo violento y agitado, exaltadamente expresivo» ${ }^{16}$. En otra ocasión, sugería yo que tal

15 Para una información completa sobre este juego-técnica de imágenes y textos vid. $R$. DE LA Flor Fernando, Emblemas: lecturas de la imagen simbólica. Madrid, 1995. Dice allí, por ejemplo: "Entre la multitud de subgéneros que podría ser traída aquí a colación, nos quedaremos con cinco que cubren, prácticamente, aunque nunca exhaustivamente, el área de lo que podemos entender por literatura emblemática, estas cinco clases establecidas de composiciones serian pues: el emblema propiamente dicho, la empresa, la divisa, el enigma y el jeroglífico... en una primera aproximación, el emblema, estrictamerte considerado, está caracterizado por la representación de una acción, de un suceso histórico, mitológico o legendario, y por estar, también, dotado de un desarrollo verbal, literario, generalmente contenido en un epigrama que da cuenta de la articulación completa de la imagen. A lo que hay que añadir, además, casi siempre, una alusión explícita a la esfera de la moral pública o privada" (pág. 52). Por otra parte, DE LA FLOR alude expresamente a la descripción lingüística (textual) de estas imágenes simbólicas, casi como a un subgénero ( $y$ este sería estrictamente nuestro caso, puesto que se describen minuciosamente imágenes que fueron pintadas pero que el lector sólo puede «ver»): "La divisa, el blasón, la heráldica, el emblema o paraemblema, se construyen también a través de su descripción literaria, ecfrasis. Estas formas alcanzan, pues, su paradójica existencia en el interior del lenguaje: existen, diríamos, depositadas como pieza retórica de relevante interés...» (pág. 105).

i6 Orozco, E., op. cit, pág. 261. Las citas que ofrece, de fray Pedro de Valderrama, no tienen desperdicio pese a que no avalan precisamente su tesis; comenta el propio autor: «a esta excitación a la lucha une, después, el mover a desollarse con los hirientes y trepidantes golpes de las 
estética, y en especial la de la violencia verbal, tenía que ver con el carácter irremediablemente militante (tanto de compromiso como de milicia) del propio modelo ideológico, al que definía, en el barroco, como devastador ${ }^{17}$. Tal esquema de intencionalidad voluntarista facilitaba, sobremanera, la divulgación de un lenguaje «de cuartel», en el sentido de su brutalidad expresiva, el desenfado de la presencia de sangre, heridas y toda clase de miserias fisiológicas, en las descripciones de lo que fuese (incluidas las más espiritualistas) y las abrumadoras alusiones al dolor, la muerte y la violencia física. Podríamos decir que tales cosas «debían» endurecer el alma de un soldado de Cristo para quien la vida no sólo era milicia sino dura milicia ${ }^{18}$. Como otra muestra de ello, en esta colección de emblemas, veamos el siguiente que es el número cuatro:

disciplinas, como si ello fuera la mejor música que Dios quiere escuchar de los hombres" (pág. 259). De hecho, el fraile citado había dicho textualmente: "mucho se agrada Dios de la música y alabanza que resulta de que os desolléis las carnes y que de vuestras pieles hagáis instrumentos para alabarle" (ibidem). Ver todo el asunto, con mayores matices y extensión: Orozco, E., Manierismo y Barroco. Salamanca, 1970, especialmente toda la segunda parte, «la literatura religiosa y el Barroco», págs. 63-145.

17 Álvarez Santaló, L.C., "La religiosidad barroca; la violencia devastadora del modelo ideológico", en Gremios, hermandades y cofradias. San Fernando (Cádiz), 1992, vol. I, págs. 77-91. Decía allí: «la mera aceptación de un modelo ideológico como la "verdadera» naturaleza y la "verdadera" sociedad, genera ya un estado de violencia interior, en tanto que la naturaleza y la sociedad reales no pueden ser ni total ni permanentemente ignoradas; la adicción al modelo ideológico puede elevar esta violencia interna a grados muy exigentes" (pág. 79). RodríguEz-SAN Pedro Dezares, en su Lo barroco: la cultura de un conflicto. Salamanca, 1988, habla de: «borrascas internas del individuo y el grupo que se expresan como tensión barroca, en ciclicas angustias de insatisfacciones y acomodos, agresividad y derrumbes (cínicos, abandónicos, autodestructivos)» (pág. 62), o también: «la promoción de lo heroico se transfiere de la hareté griega y de la virtus latina hacia el terreno de lo numinoso. El extremo deseo y su pasión puede acabar en ascética gesticulante, automortificación, y sangre como ritual expiatorio en tiempos recios.... (pág. 55).

18 Fr. Diego Estella, nada sospechoso de violencia fanática, en su Modo de predicar y modus concionandi (ed. Sagües Azcona), Madrid, 1951 (el texto es de 1576), según su editor y estudioso se refiere a la predicación como: "la lucha encarnizada que debe sostener contra todas las potestades del averno. De ahi también la necesidad de que el orador sagrado esté siempre bien pertrechado con las armas de la virtud para que pueda derrotar a todos sus enemigos" (vol. I, pág. 112). Y el propio fray Diego utiliza el símil militar a diestro y siniestro: «...porque el buen soldado de cualesquier armas se aprovecha y pelea con ellas. Sansón con una quijada de asno hizó riza en sus enemigos"; «no ha de pretender predicando, (el predicador) mostrarse letrado... porque se le embotará el filo de la espada...»; «oficio tiene el predicador peligroso... asi es menester que se escude con Dios"; "pues ¿cómo quieres tú alzar bandera contra tantos y tan graves y crueles enemigos, estando desarmado de fortaleza». Por su parte el abad Alonso SÁNCHEZ GoRDiLLO, en su Religiosas estaciones que frecuenta la religiosidad sevillana (ed. J. P. BERNALES BALLESTEROS), Sevilla, 1982, pese a que no viene precisamente a cuento, si no es traído por los pelos, se lanza de cabeza al lenguaje del que venimos hablando: «...se ponen ellos en pie a orary a acompañar al Señor, algunos armados como soldados que no solamente debe significar la guarda que los judios pusieron al sepulcro... sino también la forma de estación, vigilia y atención de guerra o milicia cristiana en la forma de orar estando en pie. $Y$ esto es congruente con que 
«Pintose al Santo puesto de rodillas, con abito de Canónigo y capirote de armiños por el pecho, y en él clavado el puñal con que los infieles le quitaron la vida. Lo roxo de la sangre salía por lo blanco de los armiños. El Santo miraba al Cielo que abierto entre resplandores y Angeles descubría una silla de gloria que le esperaba. La inscripción latina: Video Coelos apertos; la castellana: Abriole el hierro cruel / a Pedro en el pecho puertas / y él ve las del Cielo abiertas".

Y todavía, en el siguiente emblema, número cinco, vuelve a aparecer el Beato "que tenía en las manos (una salvilla de oro) ofreciendo al Cielo los dos puñales manchados con alguna sangre»; la terceta que lo acompaña insiste en el tema: "Compra Pedro con su muerte / vida inmortal y gloriosa / porque es su muerte preciosa". De estos emblemas se colgaron treinta, de modo que el baño panegírico a que los espectadores quedaron sometidos bien podría considerarse una verdadera inmersión ideológico inquisitorial. Casi ninguno tiene desperdicio pero me limitaré a reproducir media docena, por evidentes razones de prudente síntesis. Veamos por ejemplo el décimo emblema:

«Pintose al santo sentado en su Tribunal debaxo de dosel, haziendo el Oficio de Inquisidor y por lo alto baxavan dos Angeles con dos Coronas; de los quales el uno le iva a poner la Corona al mismo Santo; y el otro le iva a poner la Corona al dosel en que estaban bordadas las armas del Tribunal. La latina: Gloria et honore, y la castellana: Gozan en triunfos de Pedro / a un mismo tiempo Corona / el Oficio y la Persona».

Pese al suave hipérbaton, no parece que quedarán muchas dudas, a un «lector», de que la Inquisición toda, per sé, era merecedora de la corona del martirio (paradoja altamente barroca y que no puede ser leída, en ningún caso, como un alarde de cinismo) y del triunfo que conlleva. En todo caso, esta vez no hay casi simbolismo sino el mensaje directo del Santo (que, por cierto, ha sido sistemáticamente ascendido a tal, en el texto, pues no olvidemos que la fiesta es por su beatificación y no por su canonización) ejerciendo su oficio de inquisidor. No merece la pena subrayar el evidente retruécano en el uso de oficio, como actividad, y Oficio como institución, uso que es constante y que parece un guiño culterano en mensaje tan popularista. Este tipo de tics, que encontraremos repetidos, podrían leerse, igualmente, como un efecto buscado de atraerse la benevolencia del público a quien se «advierte», con ellos, que el autor los considera suficiente-

están asimismo mujeres, las cuales en lo corporal no pueden significar forma de soldadesca de guardas aunque en lo espiritual lo puedan ser, como son; pues la vida del hombre y la mujer es guerra en la tierra” (pág. 42). 
mente cultos como para detectar el ingenio y dignos, por eso, de ser sus cómplices intelectuales. Otra lectura, más directa, sería que el autor, “obligado " a descender estéticamente a tales abismos populistas, no ha querido dejar de sugerir, a quien lo mereciera, que él estaba capacitado para mayores empresas y que sólo la necesidad de explicar con llaneza los mensajes podía justificar una rima tan impropia de su capacidad.

El siguiente, el número catorce, resultará especialmente ilustrativo del aparato pedagógico propagandístico. Dice así:

"Pintose al Rey D. Fernando y a la Reyna doña Isabel, sentados debaxo de dosel y el Santo que se aparece entre unas nubes y debaxo de los pies una granada y en las manos del santo una Palma y Oliva, insignias de la Inquisición. La letra latina: State nunc contra inimicos nostros, y la castellana: Encarga Pedro a los Reyes / Nuestra Inquisición Sagrada / y conquista de Granada».

En resumen, parece una obra maestra de la sintesis panegírico-propagandistica; de un golpe se consiguen un puñado de mensajes de artillería pesada: que la conquista de Granada se debe a la Inquisición; que los reyes obedecen al Inquisidor y que el éxito premia el encargo y la obediencia. Estando como estamos hablando de una fiesta en Granada el efecto no puede ser más eficaz. Se observará, de paso, que, de uno u otro modo, en el diseño de la pintura de casi cada emblema se habían colocado, no sólo en lugar visible sino como elemento central, cada vez, los signos simbólicos del Tribunal del Santo Oficio, en una reiterada presencia nada subliminal y un constante aviso y advertencia.

El emblema décimo octavo introduce una novedad que ya se hacía esperar: la expresa alusión a los judios:

"Pintose un mar inquieto y alborotado; un escollo entre sus olas y dos ayres furiosos que le estan combatiendo. La letra latina: Sed frustra. La castellana: Por más que soplen los vientos / del ingrato judaísmo / siempre he sido y seré el mismo".

El tema, con la variante hereje, se retoma en el emblema vigésimo sexto:

«Pintose una paima muy vistosa y acopada a la qual unos judios infieles, tirando de las ramas pretenden inclinarla a la tierra, pero ella se subía arriba. La latina: Sed inclinata resurgit, y la castellana: Pensó el hereje cruel / inclinar la Palma al suelo / y ella se levanta al Cielo».

Por último, el vigésimo quinto emblema, que constituye un compendio de los otros mensajes: 
"Pintose sobre un monte alto una Iglesia y mas abaxo, enmedio, San Pedro Apostol y al lado derecho nuestro santo y al otro San Pedro Mártir, que estaban como calçando la silla de San Pedro Apostol y en la puerta del templo un Santo Cristo crucificado y de los pies salían tres caños de sangre que ivan a parar a los pechos de los santos. La latina: Funiculus triplex dificile rompitur, la castellana: La duración y firmeza / De aqueste llustre Edificio / La sustenta el Santo Oficio».

De cómo una frase latina, que se limita a señalar que "una triple cuerda difícilmente se rompe", se convierte en una declaración de que toda la Iglesia depende para su existencia del Tribunal, ya hemos tenido otros ejemplos. Sin insistir más en el detalle de estos emblemas y resumiendo, obtenemos que en trece (de los treinta) se han pintado las armas y simbolos del Tribunal, en propaganda inequivoca, y en sus correspondientes descripciones, en doce de ellas, se cita expresamente el Santo Oficio. Leídas las tercetas "correctamente" (es decir de acuerdo con las evidentes intenciones del "poeta") nos enteramos, quedamos advertidos o confirmados de los siguientes mensajes, bien explícitos: que el inquisidor defiende directamente a Dios (dicho por Dios mismo al Santo); que la Inquisición se sustenta de la sangre de los mártires; que el triunfo del mártir es el triunfo de la Inquisición; que martirio e Inquisición constituyen una unidad de fe; que la conquista de Granada es, prácticamente, un encargo de la Inquisición; que los Reyes Católicos obedecieron políticamente a la Inquisición; que la Inquisición es el baluarte contra el judaísmo; que religión e Inquisición son una y la misma cosa; que los miembros de la Inquisición son santos; que la duración y estabilidad de toda la Iglesia dependen exclusivamente de la inquisición; que los papas más importantes (y eso incluye a San Pedro) eran inquisidores.

Para este último mensaje se preparó "un hermoso edificio vestido de ricas sedas y telas con igual correspondencia al que fue triunfo o arco triunfal que sirvió de recibimiento al Tribunal del Santo Oficio... debaxo del se pusieron tres figuras. La primera y principal era una señora ayrosísimamente compuesta y adereçada y tenía en su mano derecha una cruz verde; ésta representava la Santa Inquisición... y por la parte de afuera, en la parte superior de las pilastras que formavan el cuerpo referido se pusieron cuatro Santos Pedros Mártires y Inquisidores y en lo más interior de ellas los Hereges a quien destruyeron estos santos y asi estaban rendidos y postrados a sus pies y presos con cadenas... S. PEDRO SUMO PONTIFI$C E$ y Sumo Inquisidor que tenía a sus pies a Simón Mago con este terceto que lo declarava: PEDRO SUMO INQUISIDOR / castigo le dió severo / a Simón Mago hechizero...". Los otros Pedros eran: el festejado (Pedro de Arbues), Pedro de Verona ( $" E l$ gran PEDRO DE VERONA / entre sus mu- 
chos trofeos / triunfó de los Manicheos") y Pedro Alejandrino, cuyos versos alcanzan el cenit de la pedagogía directa: "Pedro obispo alexandrino / a Arrio vence y como vés / le tiene puesto a los piés". Ese diálogo directo, llevando de la mano del verso los ojos del espectador a los detalles de las figuras escultóricas (aquí la imagen pintada ha sido sustituida, en una escalada de realismo sensorial, por las de bulto, vestidas y aderezadas con todos sus simbolos y señas de identidad reconocibles), no deja ya resquicio alguno a la desatención o al despiste: «...una mujer que representava la Yglesia, con su Tiara, llaves y demás insignias pontificales que le tocan, la qual estava debaxo de dosel; $y$ asi éstas figuras como las otras que quedan referidas tenían capas $y$ vestiduras ricas de diferentes colores, que temblándolas el ayre las hazía más vistosas». Paso por alto, aquí, esa conciencia estético-publicista de nuestro cronista, que pone de manifiesto la "Sabiduría» de los diseñadores (el mismo cronista, en parte) sobre los efectos sensoriales de las imágenes (señalando el movimiento de los vestidos), para concluir este segmento con la décima que coronaba todo este triunfo: "A los pies de la Yglesia (de la figura, claro) estava esta Dézima que declara el pensamiento deste triunfo; el qual es que estos quatro Santos Pedros Mártires y Inquisidores estavan sustentando la Yglesia y sus Doctores. $Y$ alude también el pensamiento a una revelación que ay de nuestro Santo en la qual dixó que los señores Inquisidores tenían sus coronas en el Cielo entre las de los Mártires". Esta introducción, como se advierte, no tiene desperdicio. Actúa como resumen esclarecedor y síntesis de los treinta emblemas anteriores; establece con toda violencia y osadía la superioridad de la acción represora sobre la de la inteligencia ("sustentando la Yglesia y sus Doctores"); "garantiza" el mensaje de que los Inquisidores deben ser asimilados a los mártires, con una «revelación» místico-milagrosa del propio beato festejado, que sabe-ha visto las coronas inquisitoriales celestes esperando a sus destinatarios. Frente a todo ello la décima en cuestión (literariamente lamentable) no pretende más que adornarse y, tal vez, facilitar la memorización: "Firme amor y Fé constante hazen de la Fé testigos / y contra sus enemigos / fuertes muros de Diamante / Pedros quatro, que en triunfante / lid contra varios errores / si se marchitaron flores / ya son del Empíreo Estrellas / siendo sus coronas Bellas / Mártires y Inquisidores".

Saliendo de esta bien concertada escenografía, pasemos a otros acordes. El cronista, que no ha desaprovechado, desde la primera letra de la dedicatoria, la más pequeña ocasión para grabar a fuego en las cabezas lectoras, la supremacía y autoridad sociopolítica del Tribunal, puede convertir, por ejemplo, un concierto en otra ráfaga de propaganda directa: "y aunque cessó el ruydo de las campanas e instrumentos, prosiguió a media 
noche una concertada música, que con todo acierto y buena disposición se dió en las puertas de las Casas de la Inquisición donde con sonoras vozes y acordados instrumentos se cantaron graves tonos en alabanzas del Santo Oficio y su esclarecido Mártir. Y lo que mas ay que ponderar en esta acción es que hasta aora no se ha conocido con certeza quien fuesse el autor de esta música; conque se reconoce que aquellos instrumentos y vozes eran solamente traydas de la devoción del Santo $y$ afecto al Santo Tribunal de la Inquisición y que ya que no podía o no se les habia permitido servirle en otra cosa le hazían demostración de su voluntad en aquel obsequio". Por cierto, me gustaría llamar la atención sobre la reiterada expresión "servir" referida a las relaciones institucionales o personales o colectivas con el Santo Oficio. Por si alguien argumentara que se trata de un vocablo de uso corriente para indicar favor o respeto, quiero recordar que el diccionario de Covarrubias (1611) dice literalmente: "Servir. Latine servire, vale obedecer a otro o hazer su voluntad y unos sirven libremente dando gusto a otros y estos sirven con su voluntad; otros sirven forçados, como los esclavos, y otros en una medianía alquilándose o haziendo concierto con la persona a quien sirven, como son los criados a los señores...". Pero no me detendré en menudencias (aunque en tales textos ninguna es inocente) y volveré a otras escenas de populismo incontestable.

La descripción minuciosa de la Procesión podría ser una de ellas por la muy evidente importancia concedida en la época a preeminencias y lugares, hábitos y puestos; la reduciré, con todo, a un solo párrafo, para llegar, después, a otras letrillas que se cantaron. Por dar satisfacción al cronista, nuestro Maestro Agustín Martínez, reproduciré uno de sus momentos cumbres y que probablemente consideraba él como prosa principesca: "Amaneció día tan deseado... y madrugaron cuidadosas las campanas a dar el alborada $y$ los buenos dias al Pueblo y a significar la Aurora, con su risa, el gozo y contento que hallava en los coraçones granadinos, con fervorosos afectos ocupados y dedicados en las fiestas de nuestro invicto mártir... y aviéndose juntado en las Casas del Tribunal todos los Oficiales, Calificadores, Abogados, Comisarios, Notarios y Familiares, se comenzó a dar la forma y salir en orden, los quales ivan todos a cavallo con ricas galas, Abitos y Veneras con un grande adorno y lucimiento, adornados los cavallos con lazos y ricos aderezos de diferentes telas de oro y plata, que dentro de la gravedad y modestia que llevaban, como Ministros de tan grande Tribunal, con la variedad de flores, formavan una alegre y vistosa primavera, donde se hallarán más ciertas las flores en sus adornos que en los más floridos messes".

Creo que será la primera vez (al menos para mí) que un desfile de personajes de actividad tan expeditivamente violenta ha sido definido como 
una "alegre y vistosa primavera"; uno no sabe qué admirar más si la «inocencia" del cronista o sus astucias retóricas. Pero vayamos a nuestros versos. Son éstos los que se cantaron en los oficios religiosos, aunque no sabemos si por profesionales o aficionados, pues el narrador se limita a señalar "y luego la Música cantó un villancico de los que se hizieron para esta festividad». Ni que decir tiene que en «la memoria» de nuestro cronista el ambiente estaba de un emotivo subido; primeramente el Secretario del Tribunal había leído la bula pontificia «con tanta autoridad, claridady distinción que aunque era en lengua latina casi la entendió todo el pueblo" (cosas así eran minucias en la emoción festiva); luego, cantando el Te Deum, "no se puede decir el gozo y lágrimas de alegría que mostró el Pueblo, nacidas de su devoción». En fin el susodicho villancico decía así, en su estribillo: «A del Tribunal de la Fé de lliberia / qué quereys? / que albricias me deys / Pues va de fiestas / Pretendeys novedades? / Ay una nueva / De quién se celebra? / De un Pedro Divino / Es de Guzmán hijo? / No, aunque en él se vió / Lo Pedro, lo Mártir y lo Inquisidor...". Tras el estribillo venían las coplas, algunas de las cuales merece la pena recordar: "Al inquisidor sagrado / al grande Pedro de Arbues / en quien oy publica el premio / quanto llegó a merecer / al que castigó al Hebreo / la ociosa esperança al ver / vivir impresa en su pecho / la ya muerta escrita ley. / Al Santo que abrasó recto / Aquellos que obscurecer / con clara sombra intentavan / la ciega luz de la Fé / Al castigo y privilegio / del judaísmo, pues fue / si para el rebelde rayo / para el rendido laurel / ... Y el tribunal granadino / en quien a un tiempo se ven / su grandeza y los aplausos / de Pedro resplandecer's. Me he permitido subrayar los mensajes más evidentes del antisemitismo militante, sencillos, directos e inequívocos. Hay algunos más en el villancico que se cantó ya en la misa: "...se començo la Missa con grande solemnidad, en la qual despues de la epistola, se cantó el siguiente Villancico». De la troba destacaré la primera estrofa: «Manden rezar la oración / del Santo a quien una noche / mató la Hebrea nación". De las coplas, las siguientes: "Para más resplandecer / logró este exemplar espejo / el ser Noble, antes que el ser / porque Pedro aun sin nacer / era ya Christiano viejo»; "Fue Inquisidor primitivo / de Aragón y tan activo / que con ardientes desseos / para castigar Hebreos / era el Santo un fuego vivo. / De aquestos pues, reduzía / a la Fé gran muchedumbre / pero al que no, luego ardia: / que al que lumbre no quería / de la Fé, / le daba lumbre. / No solo del se ausentavan / buscando parte segura; / mas viendo que los assavan / porque el sábado guardaban / huian del assadura». De mejor pluma que las primeras, estas coplas abren la caja del regocijo popular antijudio. El poeta se ha recreado en encantadores retruécanos (es seguro que estaría orgulloso de su ingenio) con la lumbre de la fe y la lumbre de la hoguera, con el ardor apostólico del Beato y el ardor de 
las llamas inquisitoriales, con la asadura del verbo asar y la asadura del cerdo (de la que huyen) ${ }^{19}$. En fin, es muy probable que algunos zagales andasen por las calles repitiendo estas consonantes o estas otras coplillas del tercer villancico que se cantó en la misa: "Maravillomé / que siendo inquisidor, / la rebeldía hebrea / quando más le aborreze, / por amor de él se encienda. / Maravillomé / que su piadosa llama / en la infiel resistencia / si como luz no emprende / ya como fuego emprenda". Como se advierte los juegos de palabras (luz de la fe y llama de amor/hoguera y fuego mortales) siguen en la misma línea de ironía, en el borde de la más soez crueldad. Precisamente a esto me refería, en el título, cuando hablaba de estética desgarrada y dura pedagogía (¿debería haber dicho soez pedagogía?). La fiesta descrita se ha organizado en tres niveles retóricos según los públicos esperados (y absolutamente en coincidencia con los preceptos aristotélicos): la fiesta del honor institucional del Tribunal, entre sus pares y para ellos; la fiesta de la iconografía emblemática, un poco para todos pero especialmente para asegurar «doctrina» y facilitar al pueblo, digamos leído, las claves ideológicas de símbolos fáciles; y, al final (al final incluso del texto descriptivo mismo), la fiesta oral y auditiva, popular hasta la chanza y el burdo retruécano, versificado, cantado, memorizable y repetitivo. Las tres fiestas de la pedagogía violenta: la fijación del esquema del poder y la jerarquía; la fijación del modelo ideológico a través de la máquina sensorial-simbólica; la fijación, a latigazos orales, de los tópicos más elementales de la militancia, el castigo y la demarcación de los enemigos irrecuperables, ya que como decía otra coplilla:

\author{
«El primero que lo hirió, \\ la espada rayo sin luz. \\ hasta la cruz le metió; \\ que en los judíos llegó \\ la crueldad hasta la Cruz".
}

\footnotetext{
Evidentemente, nuestro "poeta" no estaba, en modo alguno, dispuesto a seguir los consejos de los tratadistas eclesiásticos más serios, sobre tales juegos de sentido. En efecto, Fray DIEGO DE ESTELLA había clamado ya, cien años antes, contra tales gracias e ingeniosidades: "Tú, si quieres saber qué cosa es predicar has de huir de todo ello y abominar y maldecir tan torpes ingenios, y reirte mucho de los que los alaban... hacer a Nuestra Señora libro de la generación de Jesucristo y encuadernador al Espiritu Santo... Hacer de los cinco panes, los cinco libros de Moisés o las cinco llagas de Cristo, y de los dos peces, su divinidad y humanidad, todo esto $y$ otras cosas semejantes que he leido en libros indignos de imprimirse... son intolerable locura y desatino muy grande... esto es predicar sueños y pintar como querer y hacer del cielo cebolla... Dime ¿qué provecho se saca estar una hora haciendo a Nuestra Señora, castillo y que la torre del homenaje es la Fé... y después hacian a la misma Nuestra Señora, almena y después barbacana y ella era el castillo" (op. cit, págs. 35-37). Como se advertirá, el poeta de nuestros versos y jeroglíficos había estado haciendo, justamente, lo que el buen fraile y maestro de retórica llamaba "intolerable locura y desatino muy grande".
} 